\title{
The Offence/Defence of Infanticide: A View from Two Perspectives
}

\section{Helen Howard}

Abstract:

This article asks whether the time is right for abolition of the offence/defence of infanticide. To this end, a two-pronged approach is taken, examining infanticide initially as an offence, and then as a defence. In terms of the offence of infanticide, consideration is given to both the concept of the 'infanticidal mother', as well as to the status of infants below the age of 12 months. When considering the defence of infanticide, examination is made of the exclusive nature of the defence and of the scope for an individual to be a 'partial' moral agent. The contradictory nature of infanticide, being both inculpatory and exculpatory, suggests the need for a theoretical rationale that justifies disallowing the offence/defence to, inter alia, those women who kill their own children over 12 months and to men who suffer similar 'environmental' postnatal depression. It is suggested that women who kill their children while suffering from the 'after-effects' of childbirth are either, depending on the severity of mental disorder, fully competent and therefore criminally responsible (although perhaps entitled to a lesser sentence due to a reduction in culpability) or fully incompetent, therefore incurring no criminal responsibility at all. This proposal can be achieved by recognising that there is a place for reduced culpability or a complete absence of responsibility to fall within the current defence of diminished responsibility or within the Law Commission's recommended alternative to the insanity defence of 'not criminally responsible by reason of recognised medical condition'.

\footnotetext{
* Senior Lecturer in Law, Teesside University. The author is indebted to Dr Cath Crosby for her comments on an earlier draft.
} 
Keywords: infanticide, criminal responsibility, mental disorder

\section{INTRODUCTION}

The 'Janus-faced'1 offence/defence of infanticide is in as much need of reform/abolition as when it was considered by the Law Commission more than a decade ago. ${ }^{2}$ Despite dealing with one of the 'most disquieting'3 types of criminal behaviour, the offence/defence of infanticide offers an ideal opportunity to test competing needs within the criminal justice system. With the offence/defence of infanticide uniquely inculpating at the same time as exculpating, the harm caused to the victim must be balanced against the culpability of the defendant. Given the defencelessness of the victim and the extreme vulnerability of some defendants however, alongside often salacious media scrutiny,${ }^{4}$ a perfect balance may be impossible to achieve and the time may be right to abandon the offence/defence entirely. What is clear to academics ${ }^{5}$ and the judiciary is that " $[$ t]he law relating to infanticide is unsatisfactory and outdated. ${ }^{\prime} 6$

The offence of infanticide is a lesser charge to murder set out under s.1(1) of the Infanticide Act 1938. Alternatively, it may be pleaded as a defence under s.1(2) of the same Act. This offence/defence allows the mother who kills her child below the age of 12 months, the balance of her mind being disturbed by reason of her not having fully recovered from the birth or her still suffering the effects of lactation, to

\footnotetext{
${ }^{1}$ A Loughnan, Manifest Madness: Mental Incapacity in Criminal Law (OUP: Oxford, 2012), 226.

2 Law Commission, A New Homicide Act for England and Wales (LCCP: London, 2005), 177.

${ }^{3}$ R Ogle and D Maier-Katkin, 'A Rationale for Infanticide Laws' (1993) Criminal Law Review 903 at 903.

${ }^{4}$ See e.g. https://www.thesun.co.uk/news/3836124/mum-rachel-tunstill-stabbed-baby-to-death-jailed-forlife/. Compare https://www.2br.co.uk/news/local-news/2308772/woman-accepts-she-killed-her-baby-butsays-she-had-no-memory-of-doing-so/ (accessed on 17 July 2018).

${ }^{5}$ See e.g. Loughnan, above n.1; C Wells, 'The Impact of Feminist Thinking on Criminal Law and Justice: Contradiction, Complexity, Conviction and Connection' [2004] Criminal Law Review 88; K Brennan, 'Traditions of English Liberal Thought: a History of the Enactment of an Infanticide Law in Ireland' [2013] Irish Jurist 100.

${ }^{6}$ Per Judge LJ in R v Kai-Whitewind [2005] EWCA Crim 1092 at [140].
} 
evade the mandatory life sentence for murder. ${ }^{7}$ The offence/defence is intended to offer a more merciful outcome ${ }^{8}$ for the defendant than diminished responsibility, especially given that it can avoid the distress to the mother of an initial charge of murder or a voluntary manslaughter conviction. Wider than the defence of diminished responsibility, with infanticide there is no requirement that the defendant be suffering from a clinical disorder, nor that a causal link be shown between the disturbed balance of mind and the killing. ${ }^{9}$ While the offence/defence is rarely used, ${ }^{10}$ and was developed historically as a compassionate alternative to capital punishment for those 'illegitimate mothers' who killed their new-born infants in desperation, one view which will be examined and rejected is that infanticide is still relevant today, ${ }^{11}$ although in need of updating.

Recent cases demonstrate that the offence/defence of infanticide is still in use. In June 2017, Rachel Tunstill was given a life sentence for the murder of her new-born baby, with a minimum term of 20 years imprisonment. Tunstill gave birth in secret and claimed to have no memory of the killing. Furthermore, medical evidence suggested she was suffering from an acute stress reaction, set against a background of mental disorder, including severe depression and Asperger's Syndrome. ${ }^{12}$ This case was unusual in that the majority of women who kill their new-born infants are found guilty of, or succeed in, the defence of infanticide and rarely receive custodial

\footnotetext{
${ }^{7}$ S.1(1) Infanticide Act 1938.

${ }^{8}$ Brennan describes it as 'a more compassionate route': K Brennan, 'Beyond the Medical Model: a Rationale for Infanticide Legislation' (2007) 58 Northern Ireland Legal Quarterly 505, 534.

${ }^{9}$ C.f. s. 2 of the Homicide Act 1957 as amended by s.52(1) of the Coroners and Justice Act 2009 in which the abnormality of normal mental functioning must provide an explanation for the killing.

${ }^{10}$ Law Commission, Murder, Manslaughter and Infanticide (2006) No 304 at paras. D.6-D20: 49 cases during the period 1990-2003.

${ }^{11}$ Above n.3 at 903. This view is supported by the Law Commission, see above n.10 at para. 9.27.

${ }^{12}$ Court of Appeal, Transcript of the Handed Down Judgment, 19 July 2018, at paras. [9] and [28]-[29].
} 
sentences. ${ }^{13}$ In July 2018, the Court of Appeal quashed Tunstill's conviction for murder on the grounds that infanticide was not left to the jury and, given the conflicting medical evidence, ordered a re-trial. ${ }^{14} \mathrm{~A}$ striking comparison can be made with the sentencing of Orsolya-Anamaria Balogh who, in July $2016,{ }^{15}$ gave birth to her son in secret, cut the umbilical cord, stuffed tissues in his mouth and left him in a bin. The baby survived. Pleading guilty to attempted infanticide, Balogh was given a 12 month community order. The order was lifted in May 2017 so that she could leave the country in order to rebuild her relationship with her son. In the absence of trial transcripts and an insight into jury deliberations, it is impossible to say whether the discrepancy in the original outcomes between the above two cases was justified, nor can a prediction be made as to the likely outcome of Tunstill's re-trial. However, in light of these two decisions, questions need to be raised as to whether the offence/defence of infanticide allows for too lenient treatment of women who take or attempt to take the life of another human being, or whether a vulnerable woman who may have given birth alone and in secret should be treated so harshly by being found guilty of the murder of her child.

This article will examine infanticide in two parts; in respect of the infanticide offence, first, criticism will be made of an offence which creates the 'infanticidal woman'16 in the criminal law, and which bases criminal responsibility on the existence of a disturbance of the mind. ${ }^{17}$ Also, in considering infanticide as an offence, a challenge will be made regarding the lack of reverence paid by the criminal justice system to

\footnotetext{
${ }^{13}$ Above n.10 at paras. D.6-D20.

${ }^{14}$ The jury rejected the defence of diminished responsibility. Above n.12 at para. [13].

${ }^{15}$ http://www.wigantoday.net/news/woman-who-dumped-her-baby-in-hospital-bin-to-be-allowed-home-1$\underline{8544284}$ (accessed 9 July 2018).

${ }^{16}$ Above n.1 219.

17 Ibid.
} 
the sanctity of life. The proposition will be made that the life of an infant under 12 months is, by virtue of the infanticide offence, given less value than that of any other human being and that such a view should not be tolerated in today's society.

The second part of this article will examine infanticide as a defence. In particular, the argument will be made that, as with diminished responsibility, ${ }^{18}$ a defence ought not to recognise a reduced level of criminal responsibility - either a person is responsible or she is not. ${ }^{19}$ Rather, recognition should be given to a reduced level of culpability, but, in paying proper respect to the sanctity (and equality) of all lives, this recognition should only be given where a causal link is shown between the disturbance of the mind and the killing. In fact, where culpability is shown to be significantly reduced, it may be preferable to accept that there is no criminal responsibility at all. Finally, consideration will be given to the recommendations made by the Law Commission in its Discussion Paper on Insanity and Automatism ${ }^{20}$ which may provide a better solution to the continued existence of the offence/defence of infanticide. It will be suggested that, applying Hart's capacity theory, ${ }^{21}$ a defence of not criminally responsible by reason of recognised medical condition could be broad enough in scope to protect the woman who kills her child in circumstances where she lacked the capacity to choose to do otherwise.

\section{THE OFFENCE OF INFANTICIDE}

\footnotetext{
${ }^{18}$ See H Howard, 'Diminished Responsibility, Culpability and Moral Agency' in Mental Condition Defences and the Criminal Justice System: Perspectives from Law and Medicine, eds. Livings, Reed and Wake (Cambridge Scholars Publishing: Newcastle upon Tyne, 2015) 318-338.

19 Ibid, 326.

${ }^{20}$ Law Commission Discussion Paper, Criminal Liability: Insanity and Automatism (2013).

21 'Fairness require[s] that a man should not be punished...unless he had the capacity and a fair opportunity to avoid doing the thing for which he is punished.' H L A Hart, Punishment and Responsibility (OUP: Oxford, 1968) 190-191.
} 
The 'gender-specific'22 crime of infanticide is targeted solely at women who have given birth within the previous 12 months. Infanticide may be charged as an offence where the mens rea for murder is present and a woman kills her child under the age of one year. Section 1(1) of the Infanticide Act $1938^{23}$ states:

Where a woman by any wilful act or omission causes the death of her child being a child under the age of twelve months, but at the time of the act or omission the balance of her mind was disturbed by reason of her not having fully recovered from the effect of giving birth to the child or by reason of the effect of lactation consequent upon the birth of the child, then, if the circumstances were such that but for this Act the offence would have amounted to murder or manslaughter, she shall be guilty of felony, to wit of infanticide, and may for such offence be dealt with and punished as if she had been guilty of the offence of manslaughter of the child.

The Infanticide Act 1922, a precursor to the current statute, was introduced as a result of general opinion being against treating infants killed by their mothers as victims of an 'ordinary' murder. ${ }^{24}$ Reasons as to why the killing of an infant under 12 months has been regarded as less reprehensible are: an infant cannot suffer the same as an adult victim; ${ }^{25}$ the loss to its family is less; ${ }^{26}$ the sense of insecurity caused to society is lower; ${ }^{27}$ and the responsibility of the mother is reduced due to

\footnotetext{
${ }^{22}$ E Cunliffe, 'Infanticide: Legislative History and Current Questions' [2009] Criminal Law Quarterly 94 at 94.

${ }^{23}$ As amended by 5.57 Coroners and Justice Act 2009.

${ }^{24}$ D Ormerod \& K Laird, Smith \& Hogan's Criminal law (14 $4^{\text {th }}$ ed., OUP: Oxford, 2015) 679.

$25 \mathrm{lbid}$.

${ }^{26} \mathrm{~J}$ Keown, 'Surveying the Foundations of Medical Law: a Reassessment of Glanville Williams's the Sanctity of Life and the Criminal Law' (2008) Medical Law Review 85 at 102-103, citing Williams, The Sanctity of Life and the Criminal Law (Alfred A Knopf, 1957) 29-30.

${ }^{27}$ Ibid.
} 
the disturbance of her mind. ${ }^{28}$ While it is undoubtedly correct that the insecurity caused to society is lower, it is suggested that the other reasons should be open to challenge: all lives in being are considered equal before the law; ${ }^{29}$ the loss of a child to any family is entirely subjective; and it is culpability, not responsibility, which is reduced. ${ }^{30}$

Furthermore, the omission of the need for a causal link between the mother suffering from the after effects of childbirth or lactation and the actual killing means that certain women may kill their infants and escape the full force of a murder or voluntary manslaughter conviction. If the disturbance of the mind did not cause the killing, then a reduction in culpability seems inappropriate.

Most cases result from a guilty plea to the offence, and are accepted as such where there is evidence of emotional disturbance at the time of the offence. ${ }^{31}$ Where a woman is found guilty of infanticide, the tendency has been to deal with her leniently, ${ }^{32}$ the assumption being that she must not have been in her right mind at the time of the killing. Within this assumption, two equally incorrect views have emerged: either the mother who kills her infant must be mad, as she would not otherwise have acted contrary to her instinct; 33 or, worse, all women who have recently given birth are mad. ${ }^{34}$

\footnotetext{
${ }^{28}$ Above n.24, 680.

${ }^{29}$ See Ward LJ's comments in $\operatorname{Re} A$ [2000] 4 All ER 961, 1000: 'What the sanctity of life doctrine compels me to accept is that each life has inherent value in itself and the right to life, being universal, is equal for all of us.'

${ }^{30}$ Above n.18, 326.

${ }^{31}$ R D Mackay, 'The Consequences of Killing Very Young Children' [1993] Crim LR 21.

32 See above n.10. During a research period of 1990-2003, of a sample of 49 defendants convicted of infanticide, only three defendants were given custodial sentences.

${ }^{33}$ Wells, above n.5 at 99; A Morris and A Wilczynski 'Parents who Kill Their Children' (1993) Crim LR 31 at 36.

${ }^{34}$ Above n.3 at 904 ; Brennan, n.5 at 124.
} 


\section{The inclusive nature of the offence and the 'infanticidal' mother}

Loughnan comments that 'a finding of partial responsibility for killing (whether in conviction for a charge or in the acceptance of a plea) flows straightforwardly from the construction of the act of infanticide as an instantiation of abnormality. ${ }^{\prime} 35$ Thus, a mother who kills must be suffering from a mental disorder as no 'normal' mother would behave in this way. ${ }^{36}$ No allowance is made here for that fact that a woman may kill for reasons other than an imbalance of the mind. A lack of willingness to embark on motherhood, a desire for career progression, a failure of contraception, or the breakdown of a relationship could also be influencing factors. In allowing a conviction for infanticide with no causal link, a 'mere temporal connection'37 being required, a message is sent to all mothers that they must either be good mothers or mentally disturbed. Thus, '[t]he paradigm of good motherhood includes the myth of maternal instinct' 38 and anyone who deviates from this path by killing her child is presumed to be 'mad'. 39

A more extreme view is that ' $[r]$ unning parallel with the glorified role of motherhood, both supporting and undermining it, has been the increased medicalisation and institutionalisation of reproduction and infant development. ${ }^{40}$ The medicalised approach to motherhood arguably creates a presumption ${ }^{41}$ that all women are

\footnotetext{
${ }^{35}$ Above n.1 219.

36 J Grossman, 'Postpartum Psychosis- a Defense to Criminal Responsibility or Just Another Gimmick?' [1990] University of Detroit Law Review 311 at 315.

${ }^{37}$ A Loughnan, 'The 'Strange' Case of the Infanticide Doctrine' (2012) Oxford Journal of Legal Studies 685 at 702.

${ }^{38}$ Wells, above n.5 at 99.

${ }^{39}$ Morris and Wilcyzynski, above n.33 at 36 .

${ }^{40}$ Wells, above n.5 at 99.

${ }^{41}$ Above n.3 at 904.
} 
mentally unstable after giving birth and this presumption is underpinned by the fact that a causal link is not required for the offence to be made out. This medicalisation of infanticide has been viewed as promoting the view that 'all women are inherently mentally unstable as a result of their biological functions'. ${ }^{42}$ At the same time, the medicalisation of infanticide effectively ignores the social issues which may contribute to a woman becoming mentally ill after giving birth. Research has shown that approximately half of women who were convicted of infanticide were not suffering from an 'identifiable mental disorder'. ${ }^{43}$ The suggestion here is not that social circumstances should contribute to a defence for the woman who kills her infant, merely that there should be recognition of other factors, beyond childbirth and lactation, which can contribute to a deterioration in mental health. ${ }^{44}$ As will be suggested later, the better defence under these circumstances should be diminished responsibility or a properly drafted insanity defence.

A response to the feminist accusation that all women are viewed as unstable as a consequence of their biology is that it may be an overstatement to claim that the phrasing of the infanticide offence pathologises all mothers. ${ }^{45}$ Ogle and Maier suggest ${ }^{46}$ that as only women can experience pregnancy and childbirth, 'illnesses associated with these phenomena must inevitably be unique to women. This does

\footnotetext{
${ }^{42}$ Brennan, above n.5 at 124. See also Loughnan, above n.1, 35: 'the infanticidal woman's abnormality is depicted as less dangerous or not dangerous at all. In addition, an infanticidal woman's difference is naturalized, and,...is depicted as a product of her physiology, something which all women share'.

${ }^{43}$ P d'Orban, 'Women who Kill their Children' (1979) 134 British Journal of Psychiatry 560, cited in Morris and Wilczynski above n.33 at 35.

44 See R Roth, 'Biology and the Deep History of Homicide' (2011) British Journal of Criminology 535, 539:

'Chronic stress and social isolation...lead to physical responses that diminish maternal investment and increase the risk of maternal neglect and abuse.'

${ }^{45}$ Above n.22 at 111. Cunliffe refers to the Canadian model of infanticide which is based on the English provision.

${ }^{46}$ Above n.3 at 906.
} 
not imply inferiority'. Using a 1987 epidemiological study, ${ }^{47}$ they demonstrate that admission to hospital for psychosis was 22 times higher during the 30 days after giving birth. Nevertheless, 'there is some evidence to suggest that women who killed their newborn infants were sometimes perceived...to have been mentally weak, distressed or disturbed.'48 This out-dated rationale needs rethinking.

The appeal of this medicalised approach is that it allows for 'a lenient response for the infanticide offender without opening the floodgates to other killers or interfering with fundamental criminal law principles in relation to individual responsibility. ${ }^{49}$ The woman's behaviour could thus be explained and distinguished from other offenders by the fact that she had recently given birth. ${ }^{50}$ While fundamental criminal law principles may not have been sacrificed in order to show leniency to such a defendant, a sound underpinning rationale for the offence/defence of infanticide is absent. Of greatest concern is the notion that 'abnormality is...functioning to inculpate the individual woman charged with infanticide, ${ }^{51}$ A principled approach to the offence of infanticide is clearly lacking if it can be defined by proof of a woman's unstable mental condition.

\section{Sanctity of life}

While the inclusive nature of the offence of infanticide places its existence on shaky foundations and creates an arguably misogynistic view of motherhood, a similar negative value is placed on the life of an infant under 12 months. Despite one view

\footnotetext{
${ }^{47}$ R E Kendall, JC Chalmers and C Platz, 'Epidemiology of Puerperal Psychoses' (1987) 150 Brit J of Psychiatry 662, cited in Ogle, above n.3 at 907.

${ }^{48}$ Brennan, above n.5 at 131.

49 Ibid at 127.

$50 \mathrm{lbid}$.

${ }^{51}$ Above n.1 32.
} 
that 'killing infants cause[s] a minimum of harm',52 in allowing a mother who kills her infant to be charged with the offence of infanticide, a lower value is placed incontrovertibly on the life of an infant under 12 months. ${ }^{53}$ This seems morally wrong, outdated and no longer apt in a society proclaiming to protect 'the defenceless and innocent'. ${ }^{54}$ Unlike English law, the Irish infanticide law does not allow for a charge of infanticide in the first instance, favouring instead a murder charge. ${ }^{55}$ Concerns in Ireland were that the infanticide legislation should not 'diminish the value of infant life, or, in connection with this, the deterrent effect of the criminal law.' 56 This deviation by the Irish Parliament was viewed as 'a good compromise between the need to achieve particular practical and humanitarian objectives, while respecting a significant aspect of Catholic, and indeed wider Christian, teaching. ${ }^{57}$ In fact, if the defence of infanticide is to be retained in English and Welsh law, an initial murder charge which can be reduced at trial to an infanticide conviction may be more apposite, paying due respect to the sanctity of all lives in being.

Clearly, without such respect being paid, the English offence of infanticide risks dulling the 'bright line'58 between the value of a new-born infant and that of the unborn foetus. While the issue of 'personhood' has been provocatively discussed in the context of abortion law, ${ }^{59}$ no clear rationale is provided for treating the new-born

\footnotetext{
52 Above n.26 at 102-103, citing Williams, The Sanctity of Life and the Criminal Law (Alfred A Knopf, 1957), 2930.

${ }^{53}$ Above n.8 at 506 .

54 Above n.3 at 903.

55 S.1(1) Infanticide Act 1949.

${ }^{56}$ Brennan, above n.5 at 101.

57 Ibid at 120 .

58 A Burin, 'Beyond Pragmatism: Defending the 'Bright Line' of Birth' (2014) Medical Law Review 494 at $497:$ 'A bright line is drawn by law at birth for ascription of the rights flowing from personhood.'

${ }^{59}$ See, e.g., K Greaseley, 'Prenatal Personhood and Life's Intrinsic Value' (2016) Legal Theory 124.
} 
infant as less deserving of protection than other persons in being. ${ }^{60}$ This inequality is most evident when considering that, while suffering from an imbalance of the mind, a woman who kills her offspring would be charged with the murder of her 13 month child, but infanticide of a child below 12 months. The sanctity of life debate in relation to infanticide needs to be given recognition. As Grossman states:61 '[i]t may appear fair to exculpate mothers suffering from postpartum psychosis, but what about the child victims? Who protects their rights?' It no longer seems appropriate to use an offence, the origins of which stem from the low value placed on infant life during the $19^{\text {th }}$ century, at a time where there was high infant mortality ${ }^{62}$ combined with the stigma of illegitimacy. Given that the offence of infanticide was aimed, silently, at social rather than medical circumstances, as Brennan suggests, 'the medical basis of infanticide legislation is a legal invention.' 63

Clearly, the lack of reverence for an infant's life, where she is killed by her mother, is based more on the culpability of the mother ${ }^{64}$ than the harm to the infant. That this should be the case may be, in part, attributable to the continued existence of the mandatory life sentence for murder. The offence/defence of infanticide, like diminished responsibility, serves as 'a device for circumventing the embarrassments that flow from a mandatory sentence. ${ }^{65}$ Historically, infanticide allowed for the death penalty to be avoided more honestly. ${ }^{66}$

\footnotetext{
${ }^{60}$ Although Greaseley provides a challenging discussion on the diminishing differences between a late-term foetus and a neonate: ibid at 150-152.

${ }^{61}$ Above n.36 at 344 .

${ }^{62}$ Above $n .8$ at 522 .

63 Above n.8 at 533 .

${ }^{64}$ S Eldar, 'The Limits of Transferred Malice' (2012) Oxford Journal of Legal Studies 633 at 642-643.

65 S Dell, ‘Diminished Responsibility Reconsidered' [1982] Crim LR 809 at 814.

${ }^{66}$ Above at n.10, at para. 8.13.
} 
Of note is the fact that the Infanticide Act was passed prior to the availability of the diminished responsibility defence. ${ }^{67}$ The problem with using the defence of diminished responsibility in place of the infanticide defence is that a link to a recognised medical condition adds an additional burden to a woman who might be in denial about her mental state, ${ }^{68}$ and often has no memory of the killing. MacKay, in his research for the Law Commission, ${ }^{69}$ suggests that it is possible that a verdict of infanticide might be triggered in the cases of some defendants suffering from a 'dissociative disorder' where it would be 'less likely' to succeed in a defence of diminished responsibility. This may be so, but given that any defence which reduces a defendant's level of culpability should be robustly defensible, the absence of a link to a recognised medical condition should be a cause of concern. These issues will be addressed in relation to the defence of infanticide below.

\section{THE DEFENCE OF INFANTICIDE}

Having examined infanticide and its inclusive nature as an offence, the exclusive nature of the defence requires consideration. This will be followed by discussion of the absence of a causal link. If the defence of infanticide is used successfully, the woman need not prove a mental disorder, nor that any link existed between her disturbance of the mind and killing. ${ }^{70}$

Section 1(2) of the Infanticide Act 1938 states:

Where upon the trial of a woman for the murder [or manslaughter] of her child, being a child under the age of twelve months, the jury are of opinion that she

\footnotetext{
${ }^{67}$ Above n.24, 681.

${ }^{68}$ Above n.10 at para. 8.44.

${ }^{69} \mathrm{Ibid}$, at para. D.37.

${ }^{70}$ Above n.31 at 29.
} 
by any wilful act or omission caused its death, but that at the time of the act or omission the balance of her mind was disturbed by reason of her not having fully recovered from the effect of giving birth to the child or by reason of the effect of lactation consequent upon the birth of the child, then the jury may... return...a verdict of infanticide.

The term 'infanticide' is contradictory to its function as a 'defence'. The origins of the term are based in the language of killing, the suffix '-cide' originating from the Latin term 'occido', meaning to kill, to murder or to slay. The term infanticide as a defence is therefore a misnomer. A defence by its nature ought not to be inculpatory ${ }^{71}$ nor should it apply exclusively to only one small section of society.

\section{The exclusive nature of the defence}

A mother who kills her new-born baby as well as her 13 month old child may be charged with infanticide in respect of her new-born infant but will have to be charged with murder of her older child (although she may plead diminished responsibility as a defence); equally, a father who kills his new-born baby and who has undergone many of the same environmental problems as the mother will be subjected to a murder charge, as would the mother of an adopted infant. The arbitrary nature of these divisions has been acknowledged by the Law Commission ${ }^{72}$ but no alternative recommendations were made. Thus, while the offence of infanticide targets only a certain type of defendant, the defence of infanticide is not available to the type of defendant who may be deserving of a reduction in culpability due to circumstances

\footnotetext{
${ }^{71}$ Above n.1 32.

${ }^{72}$ Above n.10 at para. 8.13.
} 
other than the 'effect of giving birth'. Additionally, the fact that the woman need show no causal link between a recognised medical condition and the killing clearly demonstrates that a principled approach to the defence of infanticide is absent. Whether the different treatment of women who have recently given birth is justifiable must be considered.

There is a limited amount of research suggesting that the medical connection between childbirth/lactation ${ }^{73}$ allows for a distinction to be made between the 'infanticidal' mother and other types of defendant. The reasons behind the need for this distinction seem, at best, to be historical. Written about at length, ${ }^{74}$ the historical need for the defence of infanticide has long since disappeared and a new rationale for infanticide needs to be sought. The society into which the infanticide legislation was originally introduced insisted on 'female virtue, and was intolerant of illegitimacy'. ${ }^{75}$ The defence of infanticide has developed in a dishonest manner: the true reasons for its existence are not openly recognised, namely, the avoidance of the death penalty/mandatory life sentence, the distaste of judges, juries and prosecutors at the harsh outcome of a murder conviction and the need for mercy to be shown, ${ }^{76}$ and the social circumstances of a woman which fall short of a recognisable mental illness. Although a necessary defence historically, it is likely that a more open approach to the reasons for the defence and 'express recognition of the socio-economic explanation for infanticide would have been impossible' 77 to

\footnotetext{
${ }^{73}$ Ibid at para 8.26: a link may have been found. Nevertheless, 'the bulk of medical opinion supports an aetiology based on social and psychological factors'. (Brennan, above n.8 at 509).

${ }^{74}$ For an excellent historical account of the development of infanticide as an offence/defence, see Loughnan, above n.37 at 685-701.

${ }^{75}$ Brennan, above n.5 at 106.

${ }^{76}$ Brennan, above n.5 at 106-108.

77 Ibid at 136.
} 
successfully legislate. The historical need for a lenient approach to these women, in the absence of a defence of diminished responsibility, may explain to an extent why there was no requirement of a causal link between the killing and the disturbance of the mind. This flexible approach no longer seems appropriate.

\section{The Absence of a Causal Link}

While the woman who pleads infanticide as a defence must be able to show that the balance of her mind was disturbed at the time of the killing, there is no requirement that she should demonstrate she was suffering from an identifiable mental disorder, nor that the imbalance caused her to kill. The absence of a causal link allows for the merciful outcome discussed earlier but runs contrary to the other mental condition defences. The defence of insanity requires a link between a 'disease of the mind' and the defendant either not knowing the nature and quality of his act or that it was wrong. ${ }^{78}$ The partial defence of diminished responsibility requires a defendant to have been suffering from an abnormality of mental functioning which arose from a recognised medical condition and provides an explanation for the defendant's killing. ${ }^{79}$ In order to satisfy either of these defences, a defendant has to not only fulfil the criteria within them, but also satisfy the court that her actions were caused by either a disease of the mind or recognised medical condition. The absence of this causal link within the infanticide defence, admittedly, makes the defence more compassionate for women who kill their infants in desperate circumstances, however, perhaps tips the balance too far away from the harm caused in favour of the reduced culpability of the defendant.

\footnotetext{
${ }^{78}$ M'Naghten (1843) $10 \mathrm{Cl} \&$ Fin 200.

${ }^{79}$ S.2(1) of the Homicide Act 1957 as amended by s.52 Coroners and Justice Act 2009.
} 
The focus ought to be on a woman's mental health. Without an honest link to mental disorder, infanticide cases will continue to be decided in an unprincipled manner and it is possible that there will be more cases decided in the same, prima facie, unpredictable manner as Tunstill and Balogh. While Mackay points out ${ }^{80}$ that the Court of Appeal in Sainsbury ${ }^{81}$ believed there should continue to be leniency shown in cases of infanticide, ${ }^{82}$ respectfully, leniency without a sound underpinning rationale risks perpetuating a patronising view of women who kill their children at the same time as devaluing the harm caused to society.

Before examining reform proposals, what must first be considered are the circumstances under which a woman who kills her infant should be entitled to a defence. While the offence/defence of infanticide has merit on a practical level, 83 it is submitted here that these circumstances should be referable on a theoretical level to either reduced culpability or a total absence of criminal responsibility. In order first to be held criminally responsible, she must still be a moral agent.

\section{Moral agency and reduced culpability}

A principled approach to the defence of infanticide needs first to determine whether the woman is a moral agent. Loughnan suggests that the 'leniency following a conviction for infanticide (spilling over to manslaughter where the facts are

\footnotetext{
${ }^{80}$ Above n.31 at 30.

81 [1990] Crim LR 348.

82 (1989) 11 Cr. App. R. (S.) 533, 534-5. Per Russell LJ: 'of 59 cases of infanticide recorded in the last 10 years, between 1979 and 1988, not one has resulted in a custodial sentence. There have been 52 orders either of probation or supervision, six hospital orders, one of which was restricted. That then affords the pattern of sentencing for this type of offence during the last 10 years.'

${ }^{83}$ Above $n .8$ at 517.
} 
comparable) strongly suggests that defendants are viewed with a high level of sympathy and compassion, and that the infanticide defendant is regarded as less dangerous than other killers.' ${ }^{44}$ This view is supported in Mackay's sample study of 47 defendants who had killed very young children. ${ }^{85}$ Mackay's findings were that the female defendants were viewed as 'tragic cases' ${ }^{86}$ and dealt with more leniently than the male defendants who were perceived as being more culpable. Compassion has clearly been the reason for the defence, and Loughnan suggests ${ }^{87}$ that this continues to be the case. Compassion on its own should not suffice for any defence: principled grounds for exculpation should first be found. An exculpatory defence should arise due to a total lack of moral agency. A partial defence should arise where the woman is a moral agent, and therefore criminally responsible, but there are factors which reduce her level of culpability.

Capacity theory suggests that culpability arises as a consequence of both the capacity to choose and fair opportunity to comply with the law. ${ }^{88}$ While a woman may lack the capacity to choose due to the 'effects of childbirth' and, as such, ought not to be viewed as a moral agent, the effects of childbirth per se are not a sufficiently sound rationale for depriving a woman of moral agency. A link should be required to a recognised medical condition. The World Health Organisation recognises

\footnotetext{
${ }^{84}$ Above n.1 225.

${ }^{85}$ Above $n .31$ at 21.

86 Ibid at 30.

${ }^{87}$ Above n.37 at 710, citing the cases of Sainsbury (1989) $11 \mathrm{Cr}$ App R (S) 533 and Lewis (1989) $11 \mathrm{Cr}$ App R (S)

577 as examples.

${ }^{88}$ Above n.21 190-191.
} 
puerperal psychosis in paragraph F53 of the International Classification of Diseases, ${ }^{89}$ although cautions that ${ }^{90}$

[m]ost experts in this field are of the opinion that a clinical picture of puerperal psychosis is so rarely (if ever) reliably distinguishable from affective disorder or schizophrenia that a special category is not justified.

This advisory note points to a difficulty in accurately diagnosing puerperal psychosis; requiring a link to a recognised medical condition might carry the risk of holding some women to be criminally responsible who ought not to be so regarded. As recently as 2007 , Brennan stated: ${ }^{91}$ 'it is evident that there is little agreement about the causes and status of post-natal mental disturbances'. However, the absence of agreement may lead to the erroneous assumption that mental illnesses attributable to childbirth do not exist. ${ }^{92}$ The difficulty in providing a fair and accurate diagnosis is illustrated by the jury's rejection of the defence of diminished responsibility and the pending re-trial in Tunstill. ${ }^{93}$ Nevertheless, difficult cases should not deter the need to provide a principled rationale for attributing/denying criminal responsibility.

Where no criminal responsibility can be attributed due to lack of moral agency, any criminal conviction seems inappropriate. Under such circumstances, the woman should receive a complete defence. However, where moral agency is present but

\footnotetext{
${ }^{89} \mathrm{https} / / /$ icd.codes/icd10cm/F53 (accessed on 17 July 2018). The condition is often alternatively referred to as postpartum psychosis and it is suggested that these terms should be read interchangeably.

${ }^{90} \mathrm{http}: / / \mathrm{www}$.who.int/classifications/icd/en/bluebook.pdf, 19, (accessed on 17 July 2018)

${ }^{91}$ Above n.8 at 513 .

${ }^{92}$ Above n. 3 at 908.

${ }^{93}$ Above n.12.
} 
culpability is reduced, the 'half-way house'94 of a partial defence may be appropriate. ${ }^{95}$ The denial of moral agency or reduction in culpability should, in either instance, be linked to a medical condition.

\section{REFORM PROPOSALS}

The Butler Committee ${ }^{96}$ recommended the abolition of the offence/defence in favour of the further reaching defence of diminished responsibility. The Committee was of the opinion that infanticide was rendered redundant by the introduction of the partial defence of diminished responsibility. ${ }^{97}$ In addition, the Committee recognised that fathers could suffer similar stresses consequent to birth. ${ }^{98}$ The Law Commission does not share this view, preferring retention of infanticide on the grounds that it is a practicable legal solution to a particular set of circumstances'99 and that merging infanticide with diminished responsibility would have the effect of elevating the offence/defence to second degree murder. ${ }^{100}$ The prospect of labelling a woman who has killed her infant a murderer, despite her suffering from a disturbance of the mind, is a patently distasteful proposition but, given that no such reforms have been forthcoming, this argument no longer carries weight; nor, in view of the case of Tunstill, given that the judge withheld infanticide from the jury, can it be stated that the offence/defence remains a consistently practicable legal solution. Neither reason appears sufficient to shy away from reform. Abolition in favour of diminished

\footnotetext{
${ }^{94}$ Above n.37 at 705 .

${ }^{95}$ Above n.18.

${ }^{96}$ Home Office, Report of the Committee on Mentally Abnormal Offenders, Cmnd. 6244 (1975) at para. 19.27.

97 Ibid.

98 Ibid at para. 19.23 .

${ }^{99}$ Above n.10 at para 8.3.

100 lbid at para. 8.36 .
} 
responsibility would achieve a fairer balance between protection of the victim and of the vulnerable defendant.

The need for a more considered rationale behind the defence has been recognised by the Law Commission when it stated 'the partial defences to [murder] do not have defensible definitions or a rational structure'. ${ }^{101}$ Despite this assertion, no changes to the definition of infanticide are recommended, with the exception that an expedited appeal process was proposed. ${ }^{102}$ The recommendation here is that the defence of infanticide should be abolished. ${ }^{103}$ Where a woman kills her child, regardless of age, and her culpability is diminished, then she should be given the defence of diminished responsibility. In a perfect world, where her recognised medical condition is sufficiently severe to prevent her from being a moral agent, then she should have access to a reformed defence of insanity. The defence of not criminally responsible by reason of recognised medical condition proposed by the Law Commission ${ }^{104}$ would be ideal. Account should also be taken of the fact that the woman may be unwilling to plead either defence and so it should be possible for the judge to order a medical examination. ${ }^{105}$ While Grossman suggests ${ }^{106}$ that postpartum psychosis has the 'potential for manipulation and abuse', writing in 1990, the same may no longer be true today, since this form of psychosis, although difficult to accurately diagnose, is now recognised in the International Classification of Diseases. ${ }^{107}$

\footnotetext{
$101 \mathrm{lbid}$ at para. 1.70 .

102 Ibid at para. 8.4.

${ }^{103}$ With the proviso that the conviction remains voluntary manslaughter and not second degree murder.

${ }^{104}$ Above n.20 at chapter 4.

${ }^{105}$ Above n.10 at para. 8.46.

${ }^{106}$ Above n.36 at 343.

107 Above n.89.
} 


\section{CONCLUSION}

An infant under 12 months should be entitled to the same rights and recognition as any other person in being. To say otherwise is morally perverse and runs contrary to the rest of the criminal law. Unfortunately, a child of this age is in more danger of being killed by a parent than at any other age. ${ }^{108}$ The balance of the current offence/defence of infanticide is tipped far more towards the protection of the vulnerable defendant than the victim. Nevertheless, it is important to avoid the potentially 'paradoxical result' 109 that, in giving women equality before the law, they are treated more severely by being viewed as responsible for their actions and 'a gendered understanding of criminal law and justice has yet to be fully realised. ${ }^{110}$ In an age of political correctness, it is inappropriate and patronising to both inculpate or exculpate a woman on the grounds of her having recently given birth. As with other areas of the substantive criminal law, however, a sound theoretical underpinning needs to be debated prior to the implementation of any reform. The suggestion here is that the offence/defence of infanticide should be abolished, and diminished responsibility or a newly reformed insanity defence should be used in its stead. Whether a partial or total defence should be applied should depend upon whether the defendant is not a moral agent and therefore not criminally responsible or whether she is a moral agent and criminally responsible but entitled to a reduction in her level of culpability. What is also clear is that a greater understanding of postpartum psychosis, ${ }^{111}$ and the impact of such a disorder on pre-existing mental disorders, is required in order to enhance our ability to undertake the delicate

\footnotetext{
108 Above n3 at 903.

$109 \mathrm{lbid}$ at 912.

${ }^{110}$ Wells, above n.5 at 100.

${ }^{111}$ Above n.36 at 344 .
} 
balancing act needed in order to protect both vulnerable victim and vulnerable defendant in desperate circumstances. 